\title{
Three Patients Discharged From Palliative Care Unit with Home-Care Ventilator
}

\section{Palyatif Bakım Servisinden Ev Tipi Ventilatörle Taburcu Edilen Üç Hasta}

\begin{abstract}
Abdullah Kahraman Health, Van, Turkey

ABSTRACT

Palliative care services and home care services have been developing and demolishing an important health service gap in our country. The increase in number of the anaesthesiologists and other specialist physicians provide better quality service to patients; prevent unnecessary intensive care treatments and so, unnecessary high cost social security payments.
\end{abstract}

Department of Anestesiology, Van State Education and Research Hospital, Health Science University, Ministry of

Key Words: Home-care ventilator, palliative care, tracheostomy

\section{Introduction}

Palliative care is a type of care which helps patients and their relatives to cope with life threatening physical, psychological and emotional problems they face with in the terminal term conditions. Palliative care refers to the type of treatment that abates the symptoms and provides relief without medical cure. In this research, we aim at presenting three patients who are monitored with home-care ventilators in palliative care unit in our hospital.

\section{Case Reports}

Case 1: A 70 year-old female patient monitored due to esophagus carcinoma diagnosis was intubated and taken to anaesthesiology intensive care unit because of the oedema causing mass affect in the neck. Tracheostomy and percutaneous endoscopic gastrostomy were applied to the patient and the patient was accepted to palliative care unit with homecare ventilator. The patient's treatment was planned and after the essential patient training, the patient was

\section{ÖZET}

Palyatif bakım hizmetleri ve evde bakım hizmetleri ülkemizde önemli bir sağlık hizmet açı̆̆ını ortadan kaldırırken, giderek gelişim göstermektedirler. $\mathrm{Bu}$ hizmetle uğraşan başta anesteziyoloji uzmanları olmak üzere diğer uzman hekimlerimizin çoğalması ile hem hastalara daha kaliteli hizmet sunulmakta, hem hastaların gereksiz yoğun bakım tedavisi almaları engellenmekte hem de dolaylı olarak da yüksek maliyetli olan yoğun bakım tedavisi ile sosyal güvenlik kurumunun gereksiz ödemelerini önüne geçilmektedir.

Anahtar Kelimeler: Ev tipi ventilatör, palyatif, trakeostomi

discharged from the hospital after four weeks. The patient has been receiving treatment at home for three months with home care co-ordination.

Case 2: 68 year-old female patient was accepted to anaesthesiology intensive care unit with successful resuscitation after cardiac arrest. On $5^{\text {th }}$ day of hospitalization, the patient with clear consciousness and Glasgow coma scale 10, was transferred to palliative care unit with home-care ventilator, after tracheostomy was applied due detection of critical tracheal stenosis in the bronchoscopy applied after failure of extubation. The patient was discharged after the treatment was planned and the necessary training was provided.

Case 3: 52 year-old patient with amyotrophic lateral sclerosis (ALS) has been given ALS treatment for three years. The patient was intubated in the emergency service and was taken to anaesthesiology intensive care unit due to the exacerbated respiratory problems. The extubation failed and percutaneous tracheostomy with Griggs method was applied and the patient was accepted to palliative care unit with home-care ventilation. After two weeks of training and treatment planning, the patient was discharged 
from the hospital thanks to home care medical services. The patient has been monitored at home with ventilator for two months.

\section{Discussion}

Long term mechanic ventilation (LTMV) at home for treatment of chronic respiratory failure is being used extensively all over the world as a successful technique, especially for neuromuscular diseases due to its morbidity and mortality reducing effect. The practice of LTMV at home has developed in parallel with mechanic ventilation technology (1).

As a result of the improvements in health technology, lighter, convenient, cheaper and ergonomic devices suitable for household usage have been produced. Household type ventilators are improving due to demand as well. Some of these reasons for this demand are; patients prefer self-care for their basic needs and they don't want to stay at the hospital more than essentially required. The ability for self-care contributes to psychosocial development of the individual. Among some other important reasons are; reducing the number of hospitalized patients and reducing health cost (2-5).

Patient relatives, when left alone at home with the patient and the device, tend to panic because of some bad scenarios such as; the device getting out of order or stop working suddenly, the blockage of tracheostomy tube or its displacement and the patient's being short of breath. They usually demand the patient to be monitored at the hospital. Problems that may occur at home are; inadequacy of power supply, inadequacy of devices, blockage of tracheostomy tube, its displacement or impossibility of replacement and disconnection of ventilator and patient link. Solutions are; installing an alarm for power supply, chargeable systems, bag-valve ventilation, and regular maintenance, extra ventilator, paying attention to connections, low pressure alarm, adequate aspiration, and narrower tracheostomy tube. Before the patient and the caretakers leave for home with respiration device, the device is taken to the service and is followed with the caretakers. The caretaker is instructed about the maintenance of the device and how to solve the possible problems. (6).

These challenges can only be overcome with an experienced team (a specialist doctor with ventilation experience, physiotherapist, psychologist, nurse, social services expert). These requirements gave rise to palliative care services.

As a conclusion, Palliative care services have been offering services to, especially patients with cancer in our country and in the world, the numbers of people who need these services have increased as life span has extended and other chronic diseases have increased. The co-ordination of palliative care units with intensive care units provides a better quality service to these patients.

\section{References}

1. Muir JF, Cuvelier A. Evaluation of candidates for long-term ventilation. Respir Care Clin North Am 2002; 8(3): 405-418.

2. Goldstein RS, Psek JA, Gort EH. Home mechanical ventilation. Demographics and user perspectives. Chest 1995; 108(5): 1581-1586.

3. Eroğlu A, Ulusoy H, Erciyes N. Mechanical venlation at home. O.M.U. Medical Journal 2003; 20(1): 28-31.

4. Scrinivan S, Doty SM, White TR. Frequency causes, and outcome of home ventilator failure. Chest 1998; 114(5): 1363-1367.

5. Hein H, Schucher B, Magnussen H. Quality of life of various patient groups during home mechanical ventilation. Med Klin 1999; 94(1): 99-101.

6. Karakurt Z. Home mechanical ventilation. Journal of the Turkish society of intensive care. 2004; 4(3): 145-150. 